\title{
Governing Academics: The Historical Transformation from Discipline to Control
}

\section{John Welsh}

International Journal of Politics, Culture, and Society

ISSN 0891-4486

Volume 30

Number 1

Int J Polit Cult Soc (2017) 30:83-106

DOI 10.1007/s10767-016-9228-4
Volume 30 • Number $1 \cdot$ March 2017

International Joumal of Politics, Culture, and Society

Editor-in-Chief

Patrick Baert

Springer

10767 • ISSN 0891-4486
30(1) 1-118 (2017) 
Your article is protected by copyright and all rights are held exclusively by Springer Science +Business Media New York. This e-offprint is for personal use only and shall not be selfarchived in electronic repositories. If you wish to self-archive your article, please use the accepted manuscript version for posting on your own website. You may further deposit the accepted manuscript version in any repository, provided it is only made publicly available 12 months after official publication or later and provided acknowledgement is given to the original source of publication and a link is inserted to the published article on Springer's website. The link must be accompanied by the following text: "The final publication is available at link.springer.com". 


\title{
Governing Academics: The Historical Transformation from Discipline to Control
}

\author{
John Welsh ${ }^{1}$ \\ Published online: 17 June 2016 \\ (C) Springer Science+Business Media New York 2016
}

\begin{abstract}
Given the transformation in the government of academic life over recent decades, the article attempts to derive a political critique of the changing psychosocial conditions of academic life via a historical juxtaposition with the nomos of the labour camp in Solzhenitsyn's Gulag Archipelago. The aim is to address the need to think beyond normative disciplinary power, to explore a distinctly capitalist governmentality in relation to Foucault's genealogy of power and to elaborate the techniques and practices of an emergent 'meta-disciplinary' technology of labour control in academia. Therefore, a broadly Foucauldian analysis on these questions will be undertaken, and augmented with Marxian and post-Freudian insights into the role of capital accumulation dynamics, in order to texture the conventional presentation of governmental rationality. The result is a metonymic presentation of the 'camp' as a physiological structure of capitalist Modernity, whose imprint can be discerned in numerous social and institutional settings, in this case Academia and the Gulag. From this outcome, insights into the transformation of living and labouring in academia, and the effects on psychological and intellectual well-being stemming from the new complex of control can be derived. The piece concludes with some thoughts on strategies of intellectual survival in academia, on counter-conducted techniques of subjectification and on possible means of resistance in the meta-disciplinary idiom.
\end{abstract}

Keywords Camp · Governmentality · Gulag · Labour · Meta-disciplinary · Society of control · University

I want to suggest that exploitation within the contemporary Academy operates in and through technologies of selfhood that are producing new kinds of labouring subject: individualised, responsibilised, self-managing and monitoring, and increasingly carrying their office or workplace 'on board' at all times in a mobile device. What kinds of critical analysis can help us engage with this? (Gill 2014: 13).

John Welsh

john.welsh@helsinki.fi

1 Department of Political and Economic Studies, University of Helsinki, Unioninkatu 37,

Helsinki 00014, Finland 


\section{An Academic Archipelago?}

We have been witnessing a transfiguration in the ways in which academic life is being lived, and thus governed. These changes are apparently recognised, lamented and then accepted. They are profoundly historical and political. Management in government, bureaucracy, media and academia have been prosecuting 'rapid and wholesale transformation of universities in recent years' (Gill 2014: 17), reconstituting academic conditions of labouring and living in a new conceptual axiomatic that we can provisionally call 'Neoliberal' (Lazzarato 2015). A governing rationality according to these axioms is colonising our understandings of social, cultural and intellectual activities in the university generally (Gill 2014: 17). These are activities, however, in which we are all complicit (Gill 2014: 24; Saunders 2010: 60; Zuidhof 2015: 53), and as transformations in academic life and labour they are having profound effects in particular on the psychological and intellectual welfare of academic workers - the so-called 'psychosocial effects' (Gill 2014: 22). Rosalind Gill rightly points out that these effects are rarely discussed, and that despite the 'interest in reflexivity in recent decades, the experiences of academics have somehow largely escaped critical attention' (Gill 2010: 229). These experiences need to be voiced and articulated, they must be explored and ruminated upon, and most crucially they should be imaginatively conceptualised toward the key strategic question: how are we being governed? ${ }^{1}$

The justification therefore in choosing to speak of academia as the site of analysis for the new modulations of labour control lies in the need to articulate and express experiences in that environment. The initial motivation has not been to exemplify a general modulation by means of select and focused analysis of the disciplinary technology of labour in the academic setting, but the reverse, to theorise through the experienced transfigurations in academic labour control so as to contextualise micro-social experiences onto a broader macro-social and historical plane in order to make political sense of quotidian experience.

I want to connect the transformations entailed in this governing rationality-and our conative complicities by which we will our own enslavements in 'passionate servitude' (Lordon 2014: 17) — with the undertreated theme of 'academics as workers' and to look for similar historical experiences or labouring conditions (Gill 2014: 18). This way, we can texture our current understanding of those mechanisms of social control in academia that apparently remain 'frustratingly abstract and cryptically suggestive' (New Formations 2014). The ultimate significance of this analysis therefore resides not so much in 'breaking the silence' (Gill 2010), as in mobilising historical isomorphy and juxtaposition so as to better understand this silence in the direction of struggle in that environment.

The 'we' to whom I refer would be all those for whom the psychosocial effects of which I speak are of personal concern for their lives in the academic milieu. My purposes here are not only critical, and therefore neither normative nor properly scientific, but are an attempt to articulate struggle against the powers that consign. The 'we' is not a categorical social formation that can be easily identified in taxonomic social scientific terms, given the extreme diversity and range of

\footnotetext{
${ }^{1}$ This was the direct question of the Governing Academic Life conference at the London School of Economics (June, 2014), in parallel to which this article was written.
} 
academic institutions, cultures, funding arrangements, implicit social mandates, historical experiences, formal organisation, etc., across the globe. I address rather all those in the university today who recognise and are touched by what follows. This is likely the best shibboleth of a reader's inclusion in that most dubious of all structurally discrete positionalities: We.

The aim in my argument is to get beyond a rationality of labour and production that has overly privileged disciplinary rationality as an idiom of coercion and a micro-somatic complex of techniques as its principal mode. An essential theoretical point of departure is the sense that 'contemporary mechanisms of government, regulation and administration must be understood as operating according to different logics than the classic "normative" mode of "disciplinary" power' (New Formations 2014). The Taylorist rationality of the factory is clearly inadequate (Hardt 2008: 8), and the typical institution of disciplinarity seems now an 'empty fortress' (Virilio 2006: 53). ${ }^{2}$

In this direction, Mary Evans has presaged our gradual induction into 'a nightmare of a different kind, in which the horrors of force, violence, physical coercion and hardship are replaced by the slow suffocation of the spirit, the intellect and the capacity to resist' (Evans 2004: 52). Following this thought, the central idea I am therefore going to argue is over the fundamental movement in intellectual labour discipline/control from 'docile bodies' to proactive bodies as part of the emergence of a new globally strategic regime of accumulation in historical capitalism and the modality of power through which this regime is being realised. By this we can begin a movement beyond the strictly 'disciplinary', and so open the skylight to a possible set of resistance strategies and reimaginings.

For the purposes of what follows, I assume no necessary discrimination between intellectual and manual labour. It is in the objective alienation of labour via commodification, publication, teaching activities, policy documents, reports, etc., and its indexing into 'impact' and quantifiable calculation, that renders intellectual labour just as material and real as manual labour in the last analysis. Both entail an engagement with the material social metabolism; both entail profound subjectification; both entail the realisation of surplus value; and both entail a technology that draws on conative investments that evade any easy disentangling of the manual and the intellectual. The channelling of surplus value turns out then to be not so varied a phenomenon in capitalist society, when abstracted into these terms.

Whilst to speak of academic life and labour in general is to violate the great particularities and diversities across the global landscape of university institutions, the analysis below discusses an isomorphic relation running through tendencies manifest across the capitalist core states. ${ }^{3}$ It is the apparent generality of the modern 'camp' structure throughout the widespread features of transformation in universities that betrays a nomos, and it is this nomos with which I am concerned here.

Academic or intellectual labour arguably differs from contemporary manual work (i.e. garment workers) in the latter's clearer continuity within the 'disciplinary sites' of control (i.e. factory), and the former's genealogical shift into the camp rationality. Another point of presenting academia, and labouring therein, as a particular materialisation of the camp, is not to claim any unique status but both to perform an implicit immanent critique of the claims made for 'neoliberalisation' and to articulate a desire for struggle in that setting that seems increasingly acute amongst many academic labourers today.

\footnotetext{
${ }^{2}$ Incidentally, Stakhanovitism is an equally unsatisfactory characterisation of emergent academic labour forms, entailing as it did worker solidarity, mutual inspiration, space for spontaneous autonomy, and a certain politically critical trajectory (Thurston 1993: 142, 146). These features were also utterly alien to living and working in Gulag. Moreover, Stakhanovite labour techniques were a variation on a theme of Taylorism.

${ }^{3}$ This article is based on experiences at the University of Helsinki, and so the discussion that follows is not just an Anglo-American experience but something brought out starkly everywhere by austerity politics in recent years.
} 
This article then engages with three basic challenges: (1) to take a broadly Foucauldian analysis on these questions beyond the strictly disciplinary idiom that has dominated thinking on the governing of academic life ${ }^{4}$; (2) to broaden the theoretical discussion of technologies, techniques and practices of control and governmentality with historical, geographical or actual exemplary instantiations; and (3) to attempt to expand the prevalent diagnostic register into a more explicitly political exploration of the 'conditions of possibility' for struggle in the academic domain of labouring and living.

\section{Camp: A Rhizomatic Resurfacing}

Just as a return to Discipline and Punish is necessary to cast critical light upon the later Lectures on Governmentality, it is by returning to Solzhenitsyn's Gulag Archipelago that I think a critical reappraisal of the government of academia becomes possible in a way that gets beyond the disciplinary and into the Nomos des Lagers that is capitalist governmentality.

Giorgio Agamben's celebrated study established Homo Sacer as the subject of sovereign power generated in a peculiarly modern paradoxical and interstitial terrain of 'bare life' (1998). The structural constellation that has been decisive in the creation of the zone of this subject of 'bare life' has been the generalised strategic form of 'camp'. I want similarly to mobilise the camp, but in a slightly different direction: camp as a metonym of capitalist governmentality. By this, I am also attempting to explore the camp as a 'hidden matrix' and "'nomos" of the modern' (Agamben 1998: 166), but, unlike Agamben, I wish to bring out, not so much its 'juridico-political structure', as its meta-disciplinary physiology, always in motion, similar to Paul Virilio's dromological view of modernity as a 'vast camp' (2006: 54).

The succinct metonymic presentation of the prison-to-labour-camp movement is a highly pertinent, if rather contentious, poetic means of presenting the transfigurations, their operative practices and techniques. Although such a historical analysis might appear to be tenuously remote, the 'history of various forms of rationality is sometimes more effective in unsettling our certitudes and dogmatism than is abstract criticism' (Foucault 2002: 323). This is not a rash analogical move, but builds on an extant academic discourse that draws out tropes and themes of authoritarian and totalitarian exempla, in order to critique current transformations in academia (Amann 2003; Burleigh 2003: 12; Docherty 2011: 118; Evans 2004: 35-36; Geiger 2004: 243; Lorenz 2012: 600, 622). However, in this procedure, we must avoid the anachronistic and 'simple transposition of historical moulds', aiming rather to 'let the knowledge of the past work on the experience of the present' (Foucault 2010: 130-131).

Complementary to this research that parallels Soviet bureaucracy with New Public Management (NPM) in academia today is the work coming principally out of anthropological studies on 'audit culture' (Baert and Shipman 2005; Shore 2008; Strathern 2000) and technonetworked surveillance (Callon and Law 2005; Gill 2014: 22-24). These focus on quantification, calculation and the creation of indices as diagrammatic techniques and apparatuses for governing transformative 'massification', commodification, global migration and shifting capital distribution across the world's higher education landscape. With their penetrative colonisation of Lifeworlds and potential to transform subjectivities in the workplace, they

\footnotetext{
${ }^{4}$ Whilst this work began from an interest in early Frankfurt social theory, and instrumental reason in academic ranking particularly, this article has been confined to Foucault's genealogy of power for reasons of space and clarity. A critical theoretical analysis that engages with Frankfurt theorists shall be forthcoming elsewhere.
} 
are key strategic devices in the transfiguration of academic life. However, these techniques of governmentality are somewhat different from the nomos of the 'camp' in particular, and its meta-disciplinary techniques, which is the main concern of my argument here. ${ }^{5}$

With these literatures in mind, we must therefore think imaginatively on how the neoliberal transformation of academia, that is claimed to open up a previously cloistered and unresponsive space to social accountability, transparency, and competitiveness, is actually generative of the Society of Control (Deleuze 1992), wherein Poulantzas' 'peculiarly modern phenomenon' of totalitarian rationality inheres to capitalist Modernity as a recurrently instantiated historical rationality in the mode of production (2014: 107). In the very marrow of this saturating and penetrative totalitarianism lies a movement from the Sovereign's right to 'take life and let live' to a rationality driven by the logos of a vocational 'let die and make live', a genealogical movement toward a deepening and intensifying mobilisation of populations and the 'collective individuals' that constitute them (Foucault 2007: 42). This means that, despite an undoubted genealogy of power and coercion at work in the contemporary emergence of new forms and mechanisms, we must not rule out the historical surfacing of the rationality elsewhere and elsewhen in capitalist Modernity.

The great Soviet misadventure was just as much a striation on the historical plane of capitalist modernity as anywhere else, bound as it was to the spatio-temporal totality of capitalist relations, its rhythms and tempos, its imperatives and logic, and its isomorphic segmentarity of 'one world market, the capitalist one' (Deleuze and Guattari 2013: 530). Its ultimate demise was 'in no way a victory for capitalism; it was merely the breakdown for one of the forms capitalism takes' (Invisible Committee 2009: 66). There is no exclusive royal road of teleological necessity that takes us from Marxism to Totalitarianism, as posited by the likes of André Glucksmann (1975), and such historical linearity is profoundly dubious especially when it shields capitalist social relations from any compromising associations. It is therefore crucial to realise that 'it may be that older means of control', dismissed from analysis as passé, will 'come back into play, adapted as necessary' (Deleuze 1995: 182), resurfacing on the plane of History, and once more erupting on the morphonomic cartography of historical capitalism. Having said this, we must evade historicist reductionism and realise that 'the Gulag is not a residue or a sequel of the past: it is a positive present' (Foucault 1980: 136), and as such it is on present strategies and tactics of coercion that we must ultimately focus. Consideration of the past merely helps us to think critically on the present.

It is essential to note at this point that prior analyses and comparison with Gulag in studies of disciplinarity (1970s-1980s) revolved around the contemporary crisis of western Marxism (Foucault 1980: 134-145), and so failed to view the camps seriously as a set of instantiations of a capitalist axiomatic. My explorations therefore ought not to be dismissed as another scholarly ploughing of the historical rubble. What we are dealing with is a kind of rhizomatic archaeology of capitalist practices that can resurface in varied modern settings wherever the rationality or discursive conditions are formed.

\section{From Prison...}

Bless you, prison, for having been in my life!

(Solzhenitsyn 2007b: 617).

\footnotetext{
${ }^{5}$ An article treatment of diagrammatic mapping and arborescent tracing in academic rankings, as a component of the broader 'audit culture', will be forthcoming as 'Mapping Academics: Tracing the Ranking Regime in Historical Capitalism'.
} 
To Solzhenitsyn, the Soviet prison cell was a place of reflection and contemplation. Just as the cynic in his barrel, the monk in his cell or the Faustian scholar in his study have sought to labour in the ascetic seclusion of institutional isolation, so has the prison often served to grant an intellectual experience both illuminating and fruitful, capable of nourishing the "profound rebirth of a human being' (2007b: 604). This has been an implicit quality of the principle of the modern prison, as well as an explicit quality of numerous concrete historical visions of the penitentiary concept, such as at Pennsylvania's legendary Eastern State Penitentiary. How many artists, intellectuals or radicals have ruminated in imprisonment, and in so doing come to realise truths denied them amidst the smoke ( $\tau \dot{\varphi} \varphi)_{\zeta}$ ), and the ephemeral stimuli of everyday life? Boethius, Gramsci, Grotius, Lenin, Dostoyevsky, De Sade, Pisarev, Wilde, London, Emma Goldman and Solzhenitsyn himself. Tolstoy 'dreamed of being put in prison' and 'actually needed prison as a drought needs a shower of rain!' (2007b: 616). For such survivors of the Gulag labour camps as Varlam Shalamov, 'ascent, growth in profundity, the development of human beings, is possible in prison', whereas the labour camps of Gulag were 'in every way schools of the negative' (Shalamov 1994: 411). Likewise, for Yevgenia Ginzburg, 'prison ennobled people, while camp corrupted' (quoted in Solzhenitsyn 2007b: 619; Ginzburg 1975), whilst simultaneously Luchenetsky waxed lyrical that, just as 'darkness renders a person more sensitive to light', so 'involuntary inactivity in imprisonment arouses in him [the prisoner] a thirst for life, movement, work' (quoted in Solzhenitsyn 2007b: 605). To Luchenetsky, 'the quiet compels profound pondering over his own "I", over surrounding conditions, over his own past and present, and forces him to think about his future'. Prison changes a person, and though 'one can certainly debate whether this is good for revolution', or indeed the bank balance or physical health, 'these transformations always proceed in the direction of deepening the soul' (2007b: 604), or so Solzhenitsyn claimed for the political prisoner, unwittingly repeating the legitimations of Enlightenment disciplinarity.

The prison has therefore a long and esteemed place, amongst those (un)fortunate enough to have experienced such a sobering period of their lives, that ranks it as a potentially edifying and enlightening event in the dialectical journey of life. Though confined within four stout walls, locked away from the fresh air and daylight, denied a freedom of movement sometimes down to the extent of an arm outstretched, the inner recesses of thought are relatively untouched. The body might be disciplined, manipulated and made the focus of harsh somatic coercion, but thinking and the attention of the 'soul' are left relatively to their own initiatives, despite the intention of disciplinary power 'to reach something other than the body itself' (Foucault 1991a: 11). As we shall see, the docility of the imprisoned body would often be matched by the frenetic and individual activity of the mind. This cannot be said of the labour camp, where the opposite was all too common, and where the productive canalisation of libidinal investments proved a more potent bypass of dissent.

If these sentiments come across as too Platonic, romantic or even too Russian, it is also true to note that when not in solitary cells prison in Stalin's USSR was also an agonistic place of contestation and argument — 'it was a time for sharp arguments, as well' (2007a: 216) — in a manner often not dissimilar to the Senior Common Room argument, or formal university disputation. ${ }^{6}$ In

\footnotetext{
${ }^{6}$ The preponderance of testimony here from 'intellectuals' amongst the political prisoners is not simply a function of their greater tendency to put experience into memoir. Whilst I recognise the irony of relying upon intellectuals' testimony for my argument, it could be claimed that it is precisely the parallels in the experience of intellectuals who laboured and lived in the historic Gulag with the living of intellectual labourers in the current academic context that are relevant. The point is to bring out the effects of 'camp' as a resurfacing nomos and technological complex of labour control on the activity of intellectual labour. It is therefore in reference to intellectual activity in Gulag that the pertinence of the metonym is established.
} 
this case, for Solzhenitsyn, the enforced leisure, combined with the crowded proximity to other cellmates all day and everyday, cellmates of a dozen nations, creeds and political convictions, generated a degree of discussion, both speculative and mundanely political, entirely unfamiliar out there in 'Freedom'. These were 'others like yourself, doomed to the same fate' (2007a: 180); they were 'people to listen to and people with whom to compare notes' (2007a: 190). The corporate sense of being part of an almost collegial band of fellow travellers and dissertational interlocutors amongst these political prisoners (and the prison of which these writers speak was invariably an imprisonment either of isolation or alongside fellow politicals) really does shine through Solzhenitsyn's prison experience (2007a: 183).

Interrogation still hung over me, but how far it had retreated! Tomorrow I would be telling them my story (though not talking about my case, of course) and they would be telling me their stories too. How interesting tomorrow would be, one of the best days of my life! (Thus, very early and very clearly, I had this consciousness that prison was not an abyss for me, but the most important turning point in my life) (2007a: 187).

Anne Applebaum rightly points out that prisoners were able to fight back and resist the disciplinary techniques of the Soviet prison. There was greater solidarity in the prison than later in the camps where the authorities would more effectively 'divide and rule with greater ease' through a rationality of order that mobilised the techniques of temptation and promise as much as through prohibitive coercion (Applebaum 2003: 154). Likewise, prison made 'politicals' of all the prisoners in a structured anatomy of control where 'all were more or less equal' (2003: 154), as opposed to the enforced apparatus of differentiation and dynamic hierarchy later in the physiology of camps. As will be clarified further down, disciplinary power entails a surplus that engenders its own counter-conduct, just as the threat to sovereignty in the spectacle of public punishment creates its own reflexive challenge in the spectacular judicial act itself of sovereign power exercised on the body of the condemned (Foucault 1991a: 73).

However, later in camp we will see how any such surplus would be swiftly appropriated, redirected and channelled into productive activity, and the private, disputational or insurrectional moment of surplus annihilated. All this is not to say that prison was not a terrible experience: slop buckets, punishment cells, stool pigeons, interrogations, confined spaces, enforced idleness, rank air, constant surveillance, brutality, cold and damp. The daily existence of the prisoners was subject to all the quasi-panoptic surveillance and control one would expect of the disciplinary institution of prison. Solzhenitsyn mentions the regular and frequent guard's eye at the peephole in the great Sukhanovka, where the prisoner was left not 'a single moment for sleep, not a single stolen moment for privacy. You were always being watched and always in their power' (2007a: 183). Similarly, there is the constant internal relocation of prisoners from cell to cell (2007a: 209-210, 535; Applebaum 2003), and the authorities' use of the 'Nazedka' [stool pigeon, informant] (2007a: 185; Applebaum 2003). The prisoners thus undoubtedly existed under the panoptic gaze of the unseen inspector and were disciplined through the enforced spatial disposition of their bodies rendered docile.

However, for many people, prison had at least the potential to edify intellectually, satisfy socially and nourish aesthetically. In intellectual terms, there was a freedom and a scope for 'moral ascent' through thought and the ethically rigorous behaviour of the refusal (such as refusing to confess, to inform on others, or by keeping mentally active through calculating the circumference of the Earth!). There was a space for ethical practice and Enkrateia. This is the modernist Kantian freedom as autonomy, an 'intellectual and moral autonomy' (Zaretsky 2005: 163). I claim that, squeamishness at the comparison aside, work in the university has had 
much in common with the characteristics of this institutional setting. Through the figurative but historical prison comparison, I am talking of the idea of 'universities as spaces of [interpersonal] openness, intellectual freedom and collegiality' (Gill 2014: 24).

What this is to say, is that there is much in common here with the cellular, but corporate, quality to work traditionally in the disciplined academy. Academics have rarely been motivated by monetary gain. To work in disciplinary conditions, even when in the form of the 'force, violence, physical coercion and hardship' alluded to above by Evans, the activity of the intellect is not harmed, and arguably even stimulated and supported. Researchers, scholars and students have for long become accustomed to working to deadlines, consigned to labouring spaces, in cramped conditions, under-resourced and intensively examined — to name but a few techniques of academic labour discipline.

Indeed, the inclination to become an academic (particularly in the social sciences and the humanities) generally involved a temperament and personality content with long periods of social isolation and highly individualized work (Evans 2004: 119).

These disciplinary conditions elicit complaint, but are often quite tolerable for many academic labourers for whom physical comfort, luxury, monetary remuneration and unconstrained personal conditions have often played second fiddle to more vocational and aesthetic priorities. They certainly do not engender misery, and the 'slow suffocation of the spirit, the intellect, and the capacity to resist' that are proliferating aspects of the new 'nightmare of a different kind'.

Nevertheless, there is a crucial technical problem with prison, and the disciplinary rationality beyond it, within the historical morphology of capitalism in its proximity to the social metabolism. This is a problem of the techne of the social system and is summed up in a passage in Volume Two in the middle of Solzhenitsyn's musing on prison as a part of Soviet society. He remarks 'but what if one has nothing to repent of - what then, what then does the prisoner think about all the time? "Poverty and prison... give wisdom". They do. But—where is it to be directed?' (2007b: 602) This is the crucial insight. Such activity might well be intellectually enriching and vital for the ascent of the intellectual soul... but it is not productive! ${ }^{7}$

\section{... To Labour Camp}

There a convict learns to hate work. He does not and cannot learn anything else. He learns flattery, lying, petty acts and major villainies. He becomes totally engrossed in himself (Shalamov 1994: 411).

Bruno Bettelheim's analysis from his own experiences in Nazi captivity led him to conclude that 'to spend time in prison does not produce the character changes described in this paper [camp]' (1943: 446). Quintessentially, the camp was an infinitely more effective 'means of producing changes in the prisoners which will make them more useful subjects of the Nazi state' (Bettelheim 1943: 419). What we see in the metamorphosis from prison to labour camp is essentially a genealogically accretional shift in the technology of labour control from the disciplinary creation of docile bodies to the generation of proactive bodies, from the 'formation of habits' to the 'mobilisation of energy' (Rancière 2012: 31).

\footnotetext{
7 'The same could be said about Taylorism. The system of Taylorism was an extraordinary invention by an engineer who wanted to combat laziness and everything that slows down production. But one can still ask: did Taylorism ever really work?' (Foucault 1980: 162). Well, the answer is, not directly.
} 
Virilio was right that "the precious lesson of the camps and the gulags has not been heeded, because it was erroneously presented not only as an ideological phenomenon, but also as a static one, an enclosure' (Virilio 2006: 98). In short, a disciplinary view has prevailed over a governmental. The first volume of The Gulag Archipelago ('The Prison Industry') comes in the form of a social anatomy, exploring chapter by chapter the various discrete organs and tissue structures of Gulag: the Arrest, the Cell, the Interrogation, the Bluecaps (police) and the metastatic cartography of the Archipelago itself. In Volume 2, however, we get a social physiology, Gulag as a system, dynamic, nomological and 'in perpetual motion'.

For Solzhenitsyn, the labour camp (Gulag) was a matter entirely different from the prison, and at the centre of this difference lies 'the leading idea of the Archipelago-forced labour' (2007b: 10), derived from the motivation 'to get from the camps as much economic profit and production and labour as possible' (2007b: 392-393). Soul destroying, immiserating, alienating, crushing, the labour camp stripped all who were processed through it of any shred of dignity, where 'man is wolf to man' (Bardach 2003), inexorably destroying human life in the 'sewage system' of the Soviet Union as a social system.

The Gulag Archipelago is replete with references to camp-prison comparisons. The basic message is simple, that 'in comparison with prison our camps are poisonous and harmful' and it was 'really hopeless to stand fast in camp' (2007b: 605). Quoting and commenting on Bettelheim's parallel experiences in Nazi captivity, Eli Zaretsky seems to identify a similar notion.

The theme of Bettelheim's memoir is the survival of the individual personality in an environment aimed at destroying it. 'According to the well-known ideology of the Nazi state', Bettelheim wrote, 'the individual as such is either nonexistent or of no importance'. The camp was set up 'to break the prisoners as individuals' (Zaretsky 2005: 283).

But there is something vital (literally) missing in all this. Gulag camps were labour camps, not extermination camps. That annihilation was achieved through labour, through the perverse formula Arbeit macht Frei. It is not the manner in which individuals were destroyed, body and soul, but the manner in which they were 'made live' that has valence. Further, it is not the simple fact that the camps entailed (forced) labour over the (enforced) leisure of prison that is important. It is rather the way in which this labour was obtained, and through the apparatuses of forced labour how certain effects regarding power and control were realised, such as the accretional move from compulsion to impulsion, through 'technologies of self-hood' (Gill 2014), that cannot be adequately understood through the lens of anatomical disciplinary power. These were mechanisms that often impinged less on the physical freedom of the body, physical constraint being markedly less manifest than in prison (and sometimes absent altogether). It is this transformation of incarceration, from prison to camp, how this move was enmeshed in physiological imperatives of production and biopolitical reproduction, and what effects this new governmental technology of labour had on individuals 'souls', that is relevant as a comparative for a similar modality of Modernity resurfacing in academic labour today within the meta-disciplinary institution of the university.

In the Panopticon each person, depending on his place, is watched by all or certain of the others. You have an apparatus of total and circulating mistrust, because there is no absolute point. The perfected form of surveillance consists in a summation of malveillance (Foucault 1980: 158).

This was very true in camp and serves well to connect discipline to government through a meta-disciplinary genealogical moment. But Gulag was not a mere open-air panopticon; it was a society of beings, or rather an economy of beings, in which a new improvised penal 'art of 
government' had to be established by authority and corresponding 'practices of the self' had to be conjured and realised by the ingenious sons and daughters of Gulag in order to survive, not merely as bodies, but as souls.

\section{Beyond Discipline: A New Modality of Power?}

The socio-technological study of the mechanisms of control, grasped at their inception, would have to be categorical and to describe what is already in the process of substitution for the disciplinary sites of enclosure, whose crisis is already proclaimed (Deleuze 1992: 7).

So the Gulag has been touched on before in studies of disciplinarity. More broadly, there has been a crossover in critical institutional analysis from prison to educational institutions and practices ever since Discipline and Punish (1975). However, we must get beyond this to the so-called 'power at a distance' (Gill 2014: 22), from the strictly disciplinary rationality that is bound to a somatic microphysics and its institutional social infrastructure as somewhere we have ceased decisively to be already in the era of Post-War Fordism (Deleuze 1992: 3). A key aim here is to show that the elements or moments of the Society of Control, those 'metastable states coexisting in one and the same modulation, like a universal system of deformation' (Deleuze 1992: 5), are not historically a straight morphological product of the post-Fordist era, but have been a latent genealogical vector of modern capitalist rationality throughout.

So what is crucially fruitful here is not any conventional political scientific or empirical comparative analysis, but the kind of exploration that seeks to illuminate the subterranean eruptions of the rationality of capitalist governmentality, those rhizomatic instantiations of what Nico Poulantzas noted to be a 'peculiarly modern phenomenon' that possesses neither historical necessity nor teleological linearity. It has neither clear historical crystallisation nor smooth emergence, but rather strategically or tactically resurfaces here and there in various discursive and institutional settings. Supplementary to the disciplinarity instantiated in, but not limited to, the technology of Gulag, there is also instantiated a capitalist governmentality as a distinct, but not discrete, modality of power that works through, alongside and beyond disciplinary power. This is no rupture or break with disciplinary power, but an unevenly accretional and augmenting movement. Should we speak of a 'further disciplinarity', 8 rather than any break into a new modality of power? Foucault's movement from the panoptic inspector to the physiology of 'malveillance' sketched above brings out the 'meta-' of further-disciplinary techniques, practices and apparatuses.

First, we must understand what is meant by the move from 'sovereignty' and 'discipline' to 'government'. By governmental rationality, or Governmentality, is meant an 'ensemble formed by institutions, procedures, analyses and reflections, calculations, and tactics' (Foucault 2007: 108). It is exercised as a power that has a 'population as its target, political economy as its major form of knowledge, and apparatuses of security [physiological regulation] as its essential technical instrument'. So, rather than simply an anatomic-somatic microphysics, this is a power for which population - 'a multiplicity of individuals who are and fundamentally and essentially only exist biologically bound to the materiality within which they live'

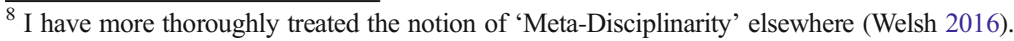


(Foucault 2007: 21) — is the most pertinent level of life at which governmental rationality is concerned, and government itself is conducted.

In the genealogy of modern modalities of power that Foucault builds throughout his corpus, we are led historically from the power of the Sovereign, through individuating disciplinary power employed somatically in panoptic institutions such as the asylum, prison, barracks and school, finally to the 'age of security', and 'Man-asSpecies' as the regulated object of this governmental power (Foucault 2003: 242). According to Foucault's historical genealogy, in contrast to the Sovereign's power that characterised the early-modern territorial-fiscal state, a field of activity began to coalesce in the 18th Century out of the crisis of Mercantilism. This field of activity is the 'economy' and constitutes the core of the (Neo-)Liberal problematic: 'how the overall exercise of political power can be modelled on the principles of a market economy' and how 'formal principles of a market economy' can be 'projected on to a general art of government' (Foucault 2010: 131). The form of political power most relevant to this broadly conceived domain of 'political economy' was no longer simply the exercise of power by the Sovereign, but the intervention of 'government' in the collective life of the population-hence governmentality - and the object of this power was no longer the Sovereign's subject, but the population itself, its continuity and its well being.

As Silvia Federici points out, the interiorisation of the mechanisms of power through disciplinary micro-physical techniques is merely the first movement of control that secures the 'collaboration of the Self' in a modality of power 'diffused and decentred through the social body' (Federici 2004: 149). It is as though the disciplinarity of prison is merely a pedagogical and preparatory moment of transformation on the road to the authentically modern destination of the 'self-management' so central to a bourgeois subjectivity (Federici 2004: 149). However, the need for techniques of coercive control inherent to the accumulative imperatives of capitalist social relations renders the realisation of this subjectivity perpetually imperfect.

Within the population in governmentality, there is the need for an individuating function in the modality of power. The given population cannot be governed, and the field of political economy cannot be intervened in, without the mereonomic establishment of individuals within the population and a particular characterisation of the social relations between them, that is, the necessary social 'depths and details' of objectification (Foucault 1980: 101). Thus, in a way that is accretional rather than successive, the role of individuating somatic disciplinary power is preserved, augmented and transfigured, dovetailed into the new modality of 'government' (Foucault 1991b: 102).

In Foucault's genealogy of power modalities from the disciplinary to the governmental, the crucial threshold consists of a movement from concern with creation and reform of the individual to a concern with the ever-greater efficacy in securing the well-being of a population, a formal population without essential definition or substantive content. In the pastoral objective inherent to the government of population, the 'collective individuals' that constitute its operative depths and details - for population conceptually presupposes constitutive individuals and vice-versa-are 'simply instrumental' in the final analysis (Foucault 2007: 42). What this world-historic 19th century shift in the modalities of power entails is then a subtle, but vital, movement from the Sovereign's negative prerogative power 'to take life or let live' to the positive Biopower to 'make live and let die' (Foucault 2003: 241). This genealogical shift does not manifest as a temporally 
phased succession, but emerges as an imbrication and overlapping, a 'dovetailing' as Foucault termed it (Foucault 2003: 242):

This technology of power [...] does not exclude disciplinary technology, but it does dovetail into it, integrate it, modify it to some extent, and above all, use it by sort of infiltrating it, embedding itself in existing disciplinary techniques.

The subject-individuating power of the disciplinary rationality that functions by neutralising, disabling, threatening, compelling, obviating, rendering passive and excluding into inertia (docility and malleability) needs now to be augmented by dynamic apparatuses that operationalise and incentivise the 'collective individual' through impulsion, mobilisation, blackmail, tease, temptation, reward, etc., but which regardless still coerce in some manner 'at a distance' and by an averted gaze.

All this is to say that what has been happening is an alteration of emphasis from the disciplinary gaze to the mobilising and rewarding mechanisms in biopolitical governmentality, functioning not by disciplinary instruction or command in the "form of the prohibition, "you must not do this"' (Foucault 2007: 66), nor via the Sovereign's 'imposition of a law that says no'. Instead, we have a disposition of techniques that engender impulsions to achieve, seek reward, gain approval, aspire, succeed and excel, along with the practical compulsions in the case of academia to acquire accreditation and symbolic qualification, that are brought to bear on the individual in the process of her biopolitical delimitation and definition in the academic knowledge-complex. The problem arises (more further down) if we question the mutual benefit and betterment, or normative neutrality, that is claimed by neo-liberal Foucauldians of this pastoral modality of government as some kind of evolution out of positive disciplinarity.

\section{Capitalist Governmentality: A Transformative Vertex}

In order to grasp fully the transfigurations in meta-disciplinarity discussed so far, the imperative logic that drives these practices, and their recurrent emergence in historical time, must be identified. There is an historical asymmetry here that belies any claim to an internally undifferentiated and normative governmentality of life in the biopolitical community. There is a fundamental social and temporal motor at work, driving the individuating function of meta-disciplinarity and its mereological apparatuses in a given population, and a logic that entails the figurative and real destruction of lives in that biopolitical multiplicity in the furtherance and successful continuity of Life. That something is axiomatic capitalism.

The normative conceptualisation of the biopolitical population often mobilised out of Foucault's Lectures seems to offer an unjustifiably homeostatic and autonomous entity that is symmetrical in its totality. The governmental rationality that inheres to the biopolitical regulation of life, and its apparatuses, does not function simply according to an abstract teleological dynamic toward the maintenance of Life itself and the simple survival of the biopolitical population at all costs. This would just be an unstriated plane of immanence, bereft of any dynamic structure or 'lines of stratification' (Deleuze and Guattari 2013: 22), denying us any analytical explanation for what is happening beyond the ahistorical. A capitalist logic works within this governmental rationality, as a stratum-generating 'tracing' on the Body-without- 
Organs, ${ }^{9}$ if you will, a phenomenon of accumulation and extraction of useful labour (Deleuze and Guattari 2013: 184). Perhaps, so as not to be implausibly paradigmatic about this, we might say it works (simultaneously?) through governmentality, producing spatially and generating historically the particularities of its concrete operations and instantiations. Ought we then speak of a capitalist governmentality?

If discipline is the subject-individuating mode, it is the dynamic imperative of capital accumulation that supplies the driving motor of individuation, establishing the multiplicity out of the totality of the biopolitical population. In mereological terms, the immanent plane of capitalist accumulation requires the realisation of spatio-temporal asymmetries of identity and difference to reconfigure and reproduce the dynamic infrastructure and differential flows internal to the biopolitical population. These membranes and penumbrae, differential barriers and limits, and variety in media are essential for the dynamic continuity of capitalist reproduction, as they simultaneously reconstitute the necessary depths and details of individuation within the population as a whole. The logic of axiomatic capitalism provides the idiomatic tracings of the capitalist socius by which the stratum of the particular is raised out of the plane of the general, in the absence of which there would be no motion, no differentiation and no individuation, and thus no biopolitical population. It is the logic of capital accumulation, and its thirst for ever-more production and growth, that motivates the internal structuring of a population so necessary for there to be an object of governmental rationality at all. In this way, there has been historically no normative governmentality, just capitalist governmentality.

In tandem with the economically productive imperative agenda of camp, there was a secondary and explicitly political agenda, destruction; destruction of dissent, organisation, consciousness; destruction of a class; a class that does not fit into the schema of orthodox Marxist theory, but a class nevertheless. Remember, a class, as a set of social relations, is just a dialectical sublation out of a capitalist mode of production, whereby 'mode of production' is taken as a social formation rather than as a specific orchestration of means of production with labour (Harvey 2006: 25-26fn). Whilst the Gulag was profoundly capitalist, it was also a historically particular emanation of a capitalist mode of production and therefore engendered a class formation particular to it - the Zeks. ${ }^{10}$ The camps were 'invented for destruction' (2007b: 7), and large parts of Solzhenitsyn's Volume Two are given over to a graduation of the Archipelago from the older disciplinary agenda of 'correction through labour' to the transformative political agenda of 'destruction through labour' (2007b: 75-76). This is especially so in the part titled 'The Destructive-Labor Camps', a title Solzhenitsyn defends for 'that's how we felt them on our pelts' (2007b: 145). This is the other (political) half to the story of camps built to mobilise productive (baldly economic) potential. Bettelheim too recalls camp as a 'laboratory' that made slaves of people by a programmatic 'disintegration from their position as autonomous individuals' (1943: 451-452). Thus, it was that the system of Corrective Labor Camps 'was a more effective means of destroying the intelligentsia than was prison. It was precisely the intelligentsia that this system killed off quickly and completely' (2007b: 631).

\footnotetext{
${ }^{9}$ The Body-without-Organs is a substrate identified as the 'plane of consistency'. It is a 'non-formed, nonorganized, non-stratified or destratified body or term' and is 'opposed to the organizing principles that structure, define and speak on behalf of the collective assemblage of organs, experiences or states of being' (Message 2010: 37-8).

${ }^{10}$ In similar vein, Solzhenitsyn claimed the Zeks to be a nation, rather than a class. Perhaps this is a result of the growing pull exercised upon him by a conservative nostalgia for the 19th century. However, his treatment was bound into an immanent critique of Stalin's theorising of nations and nationalism, which I believe heavily influenced his of choice of 'national' classification for the zeks in The Gulag Archipelago.
} 
In academia too, the emergent technology of labour control is first to correct, and failing this to destroy, dissent and recalcitrance in the event of any divergence in conative alignment from the semio-techniques of camp control. Camp was tasked with destroying dissent, disobedience and potential opposition; with destroying the political and mobilising the economic; with fabricating biopolitical 'collective individuals' - passive, proactive, and expendable. In academia, this equates with those who do not reproduce the instrumental rationality, who address counterproductive and irrelevant research questions, who do not reproduce through intellectual activity 'the daily structural violence of capitalism' (Hardt and Negri 2005, 150; Harvey 2006: 32) by their refusal to play the publication game or to endorse and collaborate in assessment and measurement exercises. The camps in the Soviet Union were destructive instruments of comprehensive political, social and economic transformation with the destruction of intellectually recalcitrant individuality as its raison d'être.

Taking the economically productive and politically destructive agendas together, 'camp' then functioned as a strategic vertex of transformation in the productive complex or regime of accumulation that was the Soviet Union emergent under Stalin, a regime that engendered the rise to hegemonic position of a new political class of administrators, police and party functionaries, and operated through the regulatory 'police' apparatuses and disciplinary techniques/practices outlined in this article. As the Soviet Union struggled to satisfy the law of combined development (Trotsky 1972: 5, 300), the exigencies of governing a population in tumult, war, revolution and mass-migration, and the need to massively expand the productive forces of the socialist society, it was the camp that emerged as the principal instrument of capital accumulation and governmentality in the absence of sufficiently developed productive technique. Today, in the prolonged spatio-temporal 'switching crises' of capital accumulation in the global core states (Harvey 2006: 428-429; 2010: 93), the 'neoliberalisation' of academia into the university-as-camp assemblage serves a similar function in the post-industrial idiom of semiotic financial capitalism. Naturally, a similar political eradication of non-productive (instrumentally reproductive) elements, and an expansion in administrators and accountants of the 'police science', will be necessary for the economic transformation to carry through, which is of course what we have been witnessing for years now.

So in a dialectical sense, camp was at once a vanguard formation of the new social order that metastasised from the prison as historical fragment and a coalescent effect of strategic crisis in the hitherto (anaemic) dominant model of capital accumulation. Crucially, the historic creation of this vertex, and the strategic project of class-power of which it was a constituent, entailed the destruction of extant social and political formations in the meat-grinder of camp life and labour. We are witnessing something similar in the university. The ongoing crisis of the dominant model of accumulation that is neoliberal capitalism, the contemporary exigencies of 'spatio-temporal fix' and 'massified' global migration, the emergence of immaterial, symbolic and affective forms of capital and labour, has necessitated the generation of disciplinary and governmental apparatuses in a new regime of accumulation. Like the Gulag, the university is being transmogrified into a strategic vertex of social relations to take on the transformative and vanguard political role in the establishment and government of this new regime. As Foucault warned, academia is therefore not 'gulag on the insidious scale of capitalism' (2010: 131), in any simple transposition, but the university is coming to manifest a contemporary aspect of that totalitarian rationality realised in Gulag as a strategic vertex on the terrain of historical capitalism.

So it is not simply a matter of the university reflecting phenomena of an external and broadly social provenance, as is often presumed. The colonising rationalities of governmentality are not "invading" the tabula rasa university and effecting transformation of academia in a socially 
normative manner. Rather, due to the university's emerging role in historical capitalism, it is being transformed in accord with the axiomatic capitalist reconfiguration of the internal infrastructure of the biopolitical population and its governmentality. This gives the University, and the struggles unfolding across its surface, a strategic political importance in the confrontation with emergent oligarchic class-power in capitalist society. But how is this struggle to manifest?

\section{Continuous Control: The Meta-Disciplinary Devices of Gulag}

In camp it is not the small ration that kills but the big one (Solzhenitsyn 2007b: 208).

So how does this biopolitical meta-disciplinary technology of intellectual labour work out? What are the 'driving-belts', and how do we feel it 'on our pelts'? What can we say of this Regime (Rhezim) of Gulag-Academia, the 'rules for living' by which we try to survive (Applebaum 2003: 185), the techniques and practices that are the 'depths and details' of this dynamic technology of control? Perhaps the greatest contradiction in academia today is 'our complicity in these processes' that produce the labouring self (Gill 2014: 24), and the move from prison to labour camp, from discipline to government, from the techniques of docility to the practices of proactivity. As we have seen, it is in prison that one is placed under the surveilling and punishing panoptic gaze. This schema is inadequate in camp, and superannuated in the new governmental technology of academic labour, where the prisoner is no longer under the gaze of authority, no longer merely compelled, but impelled; first under the 'malveilling' gaze of fellow inmates/ colleagues, and then finally under one's own psychological auspices. In this section, we shall see some mechanisms of 'governmental' impulsion that have historical parallels in Gulag. Discipline is still there (Evans 2004: 59), but the neoliberal university erects new meta-disciplinary forms of control that are 'governmental' or 'pseudo-pastoral', like the move from prison to camp, and are more effectively destructive of the individual intellectual spirit.

1. Self-Guarding/Self-Monitoring. In direct contrast to the confinement and regimen of prison, there was a much greater liberty of the body in the Zona of camp (Applebaum 2003: 183). As Gulag realised its immanent rationality, 'the guard supposedly surrounding [the zeks] became ever more illusory, ever more unreal' (2007b: 392-393), just as 'power at a distance' in the educational institution becomes more remote and unreal in a system of coercion bound, as were the zeks, by 'invisible chains which kept the natives reliably in their place' (2007b: 393). It is precisely the seeming lack of hindrance to exit in academia that resembles the parametric Zona of Gulag. This is a system strengthened and functional only due to the zeks' 'universal submission and total surrender to their situation' (2007b: 393). This is that marginal liberty of freedom of movement and choice in the disposal of one's time so celebrated by more sanguine commentators when discussing the move into the biopolitical idiom and the labour flexibility discourse. This is the spurious liberty of choice in which there is no real choice, one must run or die. Hobbes' Choice, and its sidelining of the will, is nevertheless an essential device in the transformation from docility to proactivity, and because of which the initial feeling of freedom on arrival in camp was replaced by a growing realisation of doom, desperation and cynicism (Applebaum 2003: 184; Zarod 2006: 103). Our demoralisation in the academy is not the symptom of our domination and our being bound to the technology of production and control; it is rather 
its very means. Academics today are increasingly subject to a kind of 'self-exploitation' and 'inner immigration' (Lorenz 2012: 620). These are the structures and techniques of academic labour that manifest as an intimate 'power at a distance' that 'contributes to our own self-surveillance and monitoring' (Gill 2014: 22).

It could be objected that, whereas everyone wanted to leave Gulag and no one could, everyone wants to go to academia and no one wants to leave. However, this is not a symmetrical statement. It is not that no one wants to leave the comforts of academia, a notion that is highly problematic in itself, ${ }^{11}$ but that no one really can leave academia. At least, very few can realistically leave once a considerable life commitment in time and energy has been invested. A crippling opportunity cost would have to be paid. The point about the camp metonym for capitalist governmentality is that the principal tactic of resistance in the enclosure of disciplinary rationality, that of 'escape' (AWOL patient, army deserter, truanting pupil, uncooperative psycho-analysant) is no longer possible due to the totalising and penetrative power of the capitalist mode of production through meta-disciplinary technologies in the society of control. Whither would an academic leave the university camp to go, if they were not already in a socially and financially privileged position within that institution? Just as innumerable prisoners of Gulag left camp only to hang around nearby in the so-called 'Campside' zone (Solzhenitsyn 2007b: 564-576), unable to restart a meaningful life in Soviet society at large (arguably a Gulag again on a more encompassing scale), so the academic would most likely descend into para-academic activity more precarious and exploited than before if they were to leave the academy proper. I also think that a more nuanced analysis than there is space for here would demonstrate the structured stratification internal to the university regarding satisfaction and contentment with status in that setting. For instance, ensconced senior academics and precarious junior researchers doubtless have highly variable degrees of desire to remain in the university on its current trajectories. To be a 'trustie'/'thief' in camp, on the one hand, or a 'slogger'/'last-legger', on the other, was to see camp's attractiveness in very different lights. Interestingly enough, it was the 'thieves' and 'trusties' in camp who demonstrated an active desire to return to camp from 'freedom', in the case of the former, and a willingness to remain within camp, in the case of the latter. This contrasts with the more understandably common desire to leave camp amongst the general workers, even if it meant potential death.

It is precisely the prima facie openness and ease in the terms of entry/exit from the university that recalls the apparent but superficial openness of the zona of camp. It ought also to indicate, as in the reality of camp, the power 'at a distance' that intimately controls the terms of entrance/ exit from academia actually experienced.

2. The Differentiated Ration Pot was a distribution of supplementary food, and other means of subsistence, amongst the camp prisoners conceived with the sole purpose of incentivising percentages of output above $100 \%$ of norm (those previously taken away) (Solzhenitsyn 2007b: 155).

What a merciless knowledge of human nature! Neither those pieces of bread nor those cereal patties were comparable with the expenditure of strength that went into earning them. But as one of his eternal, disastrous traits the human being is incapable of grasping the ratio of an object to its price (2007b: 155-156).

\footnotetext{
${ }^{11}$ Rosi Braidotti has articulated a growing realisation in the human and social sciences that to flee the $21 \mathrm{st}$ Century university might be a more desirable option, for the well being of more junior academics, than remaining within its tabernacle.
} 
As with the similarly opaque and mystifying commodity device in capitalist society, this really is the central device of camp control, and supplies us with a core principle of contemporary academic labour control as it is now emerging. It also is the fundamental mechanism for understanding the psychological woes of academic living. As a metadisciplinary device, it is couched in the ideological rhetoric of 'competition', but merely turns the object of competition inward, penetrating and destroying the dignity of the individual.

Key to the functioning of the 'differentiated ration pot' is the tactic of Limitless Postponement that one finds running right through so many topological features of the Society of Control (Deleuze 1992: 5). For instance, it is limitless postponement of remuneration, promotion and security of position that incentivises junior researchers to allow their journal publications to be profitably published by presses without remuneration, on the perpetually postponed promise that one day such publications will get them a salaried position. Like the promise of early release from camp, such promises rarely materialise. However, labouring in pursuit of 'the big ration', under endlessly postponed conditions of remuneration and security, exploits our dedications and 'eat[s] people alive'. Mary Evans rightly analyses labour in the academy as

by its nature endless; the perfect study, the perfect explanation, the perfect book is always waiting to be written. Place this specific imperative alongside Protestant expectations about work as the route to heaven and a noxious cocktail of obsessive, workaholic values is created (2004: 99).

However, through the 'differentiated ration pot', we can apprehend how the impelling labour imperative of limitless postponement inheres to the very anatomical structure and physiological systemic relations of the regime itself, and does not require any etiological reference to wider cultural mores nor to ahistorical personal proclivities specific to academics.

Some exemplary technical instruments that erect the framework for this logic might include the tenure-track system, the widely distributed 'publish or perish' aphorism, résumé-building, unpaid labour in teaching or the ratio of limited postgraduate funding pools to accepted positions.

3. The Brigade of workers in the labour camps was a signal creation of the metastasis and maturation of the productive apparatus of Gulag. Quite simply, work groups would be organised with a Brigadier as chief, often with two such Brigadiers in order to stimulate intra-brigade competition and enmity. In contrast to the isolation of disciplinary techniques, the brigade offered a more intimately effective means of enforcing control on labourers by the self-policing of the population of prisoners.

The brigade is clearly a disciplinary institution by descent (Herkunft), born of clearly panoptic situations such as those where 'hundreds of prisoners are clumped together in a small area visible to the naked eyes of the supervisors, and hardly has anyone of them stopped moving than he is immediately conspicuous' (2007b: 156), such as at worksites on the Belomor Canal. However, in inauspicious working conditions (remote postings, few guards, dispersed worksites), how was control guaranteed? Much thought was applied, and the brigade was invented; from disciplinary surveillance to metadisciplinary malveillance. The brigade augments disciplinary power with the new metadisciplinary modality of power; it does not replace it.

In reference to the brutal mutuality of "encouragement" in the brigade, Solzhenitsyn sarcastically remarked on "how the brigade serves the psychological enrichment of its 
members, the prodding, the surveillance, and the heightened sense of dignity' (2007b: 157), and how 'consistent with the purposes of the brigade, worthy tasks and brigadiers... are selected' (2007b: 157). No longer a collegial band of fellow travellers, as in prison, but vicious and suspicious rivals for the food of the differentiated ration pot. Bettelheim also noted the highly effective meta-disciplinary work-group malveillance in Nazi labour camps contrived by the SS through the key technique of always punishing collectively for individual transgressions (Bettelheim 1943: 436, 452), and which functioned solely from the active complicity of a decisive majority of the group (1943: 444).

Here, we have both the compulsion to adapt to situations and the notion of a seemingly preferable form of ordering production, but simultaneously a greater penetration and intensification of the stresses brought to bear on the individual in this new technology of labour. Make live and let die. The result is a greater loss of our 'souls' (or for Bettelheim, 'ego') through instrumental adaptation of one's subjectivity to the alienated circumstances of systematic control (1943: 431). After all, 'what is there to which people cannot adapt? It would be crude on our part not to look closely and observe how the brigade sometimes became a natural constituent cell of the native society of the Archipelago, of the same kind that the family is in freedom. I myself knew such brigades - and more than one too. True, these were not brigades on general work - where someone had to die because otherwise the rest could not survive' (2007b: 157).

Instances of this include the intra-faculty competition for funding allocated from centralised university decision-making, whereby faculty deans and institute directors become brigadiers in the securing of means of subsistence for the brigade, and thus making of them executants of police power rather than leaders of resistance. Similarly, the creation of internal faculty or university publication databases establishes the structure of malveillance, whereby the brigade of academic workers struggling to meet the output for the differentiated ration pot can see who the weak link is in the brigade, who threatens the subsistence of the whole, and so who must be eliminated in the next round of cuts, sidelined from a share of the ration pot, or otherwise 'encouraged' to buck up.

4. Then there is the 'Socially Friendly Element' (Solzhenitsyn 2007b: 92-93, 425-446). These are those who are constituted as a social category and whose existence and behaviour instrumentally serve the dominant power structure, deepening the rationality of control and supervision that is necessary for the power of authority 'at a distance' to function. In camp, they were the 'thieves', the historic Russian blatnoyie deemed in the syllogistic Soviet dogma to be safely criminal rather than dangerously political, thrown in with the politicals to 'gnaw on their flesh' and keep them in line through vampiric terror (Solzhenitsyn 2007a: 502-512; 2007c: 291). As merely 'the rear ends of the Bluecaps [authorities, state police]', the 'thieves' were a continuation of the machinery of oppression into the very tissue of camp life. They served to divide the politicals, individuate/ isolate them, and sap their will to organise and mutually support one another. Is this the swelling rank of administrators today, taking their pick of the nicest campus buildings, secure contracts, university budgets, and controlling the allocations of rooms and resources to the academics, as the thieves did with the duffel bags and victuals of the politicals at all and every encounter in the camp system? 
5. The Trusties (pridurki) were those who accepted privileged positions in camp. They were tempted or induced 'into collaboration with the repressive system, raising them above the others, and granting them privileges which allowed them, in turn, to help the authorities exert their power' (Applebaum 2003: 331). These were the subaltern strata of work assigners, clericals, orderlies, kitchen staff, personal attendants, etc. The trusties did not kill or torture in Gulag, but they 'participated in a system that forced prisoners to work to their deaths' (Applebaum 2003: 336). In academic terms, those who occupy 'trustie' positions in university departments, faculty boards, etc., are often well-meaning people with their own professional problems, but by accepting their privileged position and executing their function in that position, they are enablers of a system of 'power at a distance'.

There are many motivations to assume such positions, but the physiological dynamic of 'make live and let die' turns such a decision into one of vocational survival. In long-term conditions of retraction and retrenchment, this is a survival systemically at the expense of others. Further, trusties tended to be selected from the 'socially close' elements (thieves), just as in academia where they tend to be selected from the least critical, the least theoretical and the most rationally 'disciplined', as they move toward more acceptable 'entrepreneurial and scientific criteria' in their orientations (Brown 2011: 128). For those who consider this a harsh personal judgment, it is not one I hold in isolation. For Mary Evans, 'the eager recruits to law and order who have made possible every fascist regime in history found a civilian, and respectable, place for themselves in the QAA [a UK higher education assessment body] and its endorsing institutions' (2004: 126). Thus, universities seem 'to contain at least enough people willing to learn to live to control others through new patterns of surveillance' (2004: 126), and this surveillance - as with the 'thieves'-is suffocatingly intimate, yet impossible to get hold of pro forma.

One hears often that to survive vocationally in the university today, one must 'play the game', which is shorthand for complicity and collaboration in the rationality of capitalist governmentality in academia. This is a predictable apologetic argument given that the majority of camp survivors probably owed their survival to their complicity in reproducing the rationality of Gulag (Applebaum 2003: 335), and survival in academia bears the same mark. However, in universities, the administrator is increasingly more a role than a discrete personage, with academics more and more taking an 'admin' route, since 'career opportunities for the potential assessor are considerable' in our times of assessment mania (Evans 2004: 35). To Primo Levi, the 'hybrid class of the prisoner-functionary' constituted both camp's 'armature' and its 'most disquieting feature' (Levi 1989: 27). Likewise, multiplying the cadre of administrator-academics is to turn living Labour against itself and 'to encourage structures which quite explicitly endorse and reward competition between individuals' (Evans 2004: 119), between those who would otherwise organise a greater solidarity of interest against the 'socially friendly element' and the authorities. But this tactic of power can engender its dialectical opposite. Perhaps we should look to an alliance with the 'thieves', an alliance with those fractions of the administration that are increasingly subject to domination, exploitation and precarity, just as those admin-academics amongst us seek 'trustie' positions in the power structure. Thus, we can create new lines of solidarity with the troubled groups of disaffected office staff, interns, cleaners, caterers, etc. (Eve 2012). This strategy was actually pivotal in the final defeat of Gulag in the 1950s (Solzhenitsyn 2007c: 307). 


\section{Soul Mange? Techniques of Subjectification}

We must open our eyes on the contrary to what enables people there, on the spot, to resist the Gulag, what makes it intolerable for them, and what can give the people of the anti-Gulag the courage to stand up and die in order to be able to utter a word or a poem (Foucault 1980: 136).

We have seen how the relative ineffectiveness of disciplinarity as a modality of power lies in the surplus entailed in the activity of that power as realised through its techniques. Resistance is engendered by power itself in its operation and realisation (Foucault 1991a: 201). The relative effectiveness of meta-disciplinarity in capitalist governmentality stems from the apparent absence of such a surplus in this modality. As such, resistance to power cannot rely upon the surplus of disciplinary power to provoke or establish the terms of resistance. A modality of power predicated on 'proactivity' must be met with a resistance characterised by a heightened sensitivity that takes the initiative and creates the conditions of possibility for its own practices of counter-conduct. It is precisely this misapprehension that probably explains the dumbstruck inability of academics, accustomed as they are to thinking through disciplinary power, to begin even to imagine strategies of resistance, or properly counter-conduct, to the modality of capitalist governmentality. This is where we are.

We have been concerned with the effects of the transfiguration in the governing operations of academic life and labour and 'by what this does psychosocially to us, how it produces new structures of feeling in the academy' (Gill 2014: 22). For Solzhenitsyn, the labour camp produced 'soul mange' (2007b: 621-622, 640), a fundamental corruption of the human character. We can extend or reduce this concept and speak of 'intellectual mange'. We hear so much of academic researchers who increasingly have 'felt spiritually and ethically bankrupt' (Sparkes 2007: 521). This is a reformulation of the industrial pathology of capitalism that forces the individual to internalise the productive apparatus, moulding the worker's personality and subjectivity for purposes of command and organisation (Virno and Hardt 1996: 133), resulting in 'inner immigration' and self-exploitation (Lorenz 2012: 620), and the territorialised hijacking of a libidinal economy subjectivised. One recalls in this capitalist pathology Marx's 'manufacturing moment' that 'converts the worker into a crippled monstrosity by furthering his particular skill as in a forcing-house, through the suppression of a whole world of productive drives and inclinations' (Marx 1990: 481). However, it is not so much a suppression, as a formidable mobilisation with which we now must reckon.

The original panopticon of Bentham was conceived on a utilitarian principle of improvement, as an 'articulation of an Enlightenment philosophical idea as well as marking a changing paradigm in social reform from physical punishment to visual control' (Chapman and Ostwald 2006: 1). The apparatuses of capitalist governmentality in the society of control have no such imperative necessarily, and as the memory of the disciplinary fades, a 'nightmare of a new kind' can increasingly dominate - a biopolitical community of expendable 'collective individuals', who, if in refusal will not be 'made live', will rather be 'let die'.

It is important to remember that Bentham's panopticon was not derived merely as a terroristic weapon of power and domination. The discipline and punishment occasioned by disciplinary mechanisms was/is more than a sophisticated machinery of ever-greater potencies of the sovereign's revenge. It was conceived, taking the carceral system as an example, 'in order to organize good prisons, where people could be treated, reformed as in a disciplinary institution' (Foucault 1983). This is why Surveiller et Punir might have better been titled 
Surveiller, Punir, et Améliorer (To Discipline, Punish, and Improve/Better), granted with a little conscious irony. Discipline as a mode of power was therefore always more than an institutional typology, and more than a sum of the techniques of disciplinary power found in those institutions, it was a 'disciplinary system' that is 'much more a kind of rationalité than a total institution' (Foucault 1983). In this way, disciplinary rationality is entailed in governmental rationality, swallowed and developed by it, furthered by it. Disciplinary rationality and governmental rationality are variant modes, but are touched by the Enlightenment trope of improvement: improvement of the Body (discipline), improvement of the Population (government) and improvement of the Soul (pastorate). It is in this respect that both modes are bound into the Dialectic of Enlightenment.

It is insinuated by some (Ewald 1991; Gordon 1991; McNay 1992: 61) that governmental power offers an emancipatory trajectory in the genealogy of power in terms of personal liberty and government of the Self. Disciplinary power 'takes the form of an exhaustive surveillance of individuals so that they are all constantly under the eyes of the sovereign in everything they do' (as one can see in the 19th-20th centuries' educational institutions), meaning that it is panoptic. On the other hand, governmental regulation provides a 'set of mechanisms that, for the government and those who govern, attach pertinence to quite specific phenomena' (Foucault 2007: 66), leaving a broad range of activities and spaces quite untouched and free from interference. Power is experienced less as a tangible and immediate command and control or intrusion for most people most of the time in the discursive field on which power works. Rather than being disciplined and punished, mechanisms like internal markets, rankings and assessment exercises supply incentives and rewards to operationalise and mobilise those behaviours of individuals that are biopolitically favoured.

In the carceral archipelago of Gulag, what we are witnessing is a rationality bereft of the theme of improvement through disciple or pastoral government. These have been replaced, within particular apparatuses of governmental rationality, by the vengeful power of the sovereign affirmed at multiple points by spectacular violence and a telos of annihilation driven by the accumulation imperative of an axiomatic capitalism 'occupying the position of the sovereign without dispensing any meaning' as tyrannical primum movens of Gulag (Holland 1998: 67). However, in the camp paradigm, one can no longer truly say of this machinic capitalism (that 'sits mute on the throne of the sovereign') that 'what is owed is merely one's work, one's quantified labor-power rather than one's life' (1998: 67). On the contrary, in the biopolitical community, what is owed by the 'collective individual' is its labour-power and its life. Failure to pay the debt of one (to be 'made live' through labour) is to forfeit the other (to be 'let die').

One suspects that this missing link in the history of Gulag helps to explain the fairly impoverished lifespan of the institution in world historic terms and its ultimate demise rather than dialectical transcendence. A crucial component in the rationality of the Dialectic of Enlightenment was missing. There was no improvement (even if understood in merely instrumental terms), no 'ascent', only 'corruption'. If a new technology of labour is being established in the university according to a similar governmentality operative to the logic of a sovereign imperative of capital accumulation, serious questions arise.

So is it sufficient merely 'to make a shelter for oneself' (Levi 1989: 25), to develop an ahistorical and cynical survival niche lodged perennially at the end of history in The Grey Zone? There may be no dialectical teleology to History, but that does not invalidate dialectical thinking, nor does it preclude an appreciation of the dialectical relations between things. The aim here is not simply to combat 'the cop in the head', or the rot in the soul, but to apprehend and engage with the material techniques and practices that every second reconstitute what Rancière calls 'the new terrors and manipulations of powers' (2012: 123). Are we to bow before the instrumental 
rationality and to accept that 'the best society, then, will be the one that exempts the power of thinking from the obligation to obey' (Deleuze 1988: 4), not merely for the philosopher but for the intellectual wellbeing of us all? Is such an interstitial niche a requisite for the survival of the 'soul'? What if to think is to desire, and to desire is to think? Are both then subordinated; both rendered obedient to the imperatives of being ever more productive/anti-productive?

As academics, we seek for the sophisticated analysis of power, we value subtlety and we crave intellectually legitimatising and justificatory argument for what we do. However, politically, this puts us in poor stead, and I follow Rancière's post- 68 realisation that it is fatal to over-theorise resistances. We therefore fail to see that this academia of the governed is as 'a game that had its rules, a conspiracy with its mode of circulation, a "happy war machine"' (Rancière 2012: 124). So, as such, 'against the army of power it is always necessary to set in motion a kind of war machine, but also - and there is nothing sad about this - that rebellion has no legitimacy, simply a logic'. In that logic, 'there is never in the last instance any other alternative than to obey or resist power' (2012: 123), and there is no cunning of reason, historical necessity nor sociological category that will provide an answer. I suspect most of us who get this far already know the answer and need not puzzle over 'what is to be done?' It is that which comes least naturally to the cerebral: refusal, risk, courage and a willingness to die... professionally.

\section{Compliance with Ethical Standards}

Conflict of Interest John Welsh declares that he has no conflict of interest.

Funding This study received no funding.

Ethical Approval This article does not contain any studies with human participants or animals performed by any of the authors.

\section{References}

Agamben, G. (1998). Homo Sacer: sovereign power and bare life. Stanford: Stanford University Press. Amann, R. (2003). A Sovietological view of modern Britain. The Political Quarterly, 74(4), 287-301. Applebaum, A. (2003). Gulag: a history of the Soviet camps. London: Penguin.

Baert, P., \& Shipman, A. (2005). Universities under siege? European Societies, 7(1), 157-185.

Bardach, J. (2003). Man is wolf to man: surviving Stalin's Gulag. New York: Scribner.

Bettelheim, B. (1943). Individual and mass behaviour in extreme situations. Journal of Abnormal and Social Psychology, 38(5), 417-452.

Brown, W. (2011). Neoliberalized knowledge. History of the Present, 1(1), 113-129.

Burleigh, M. (2003) Assessment. Times Higher Education Supplement, 4.

Callon, M., \& Law, J. (2005). On qualculation, agency and otherness. Environment and Planning D: Society and Space, 23(5), 717-733.

Chapman, M., \& Ostwald, M. (2006) Circularity, power and the technologies of seeing: panopticism and its antithesis as spatial archetypes of visual contraception in space. Design research society. International Conference in Lisbon (IADE):1-11. http:/www.iade.pt/drs2006/wonderground/proceedings/fullpapers/DRS2006_0163.pdf.

Deleuze, G. (1988). Spinoza: practical philosophy. San Francisco: City Lights Books.

Deleuze, G. (1992). Postscript on the societies of control. October, 59, 3-7.

Deleuze, G. (1995). Negotiations 1972-1990. New York: Columbia University Press.

Deleuze, G., \& Guattari, F. (2013). A thousand plateaus: capitalism and schizophrenia. London: Bloomsbury. Docherty, T. (2011). For the university: democracy and the future of the institution. London: Bloomsbury Academic. Ewald, F. (1991). Insurance and Risk. In: Burchell G, Gordon C and Miller P (eds) The Foucault Effect: Studies 
in Governmentality. Chicago, IL: University of Chicago Press, 197-210.

Evans, M. (2004). Killing thinking: the death of the universities. London: Continuum.

Eve, M. (2012) Unpaid research internships reveal a dangerous hypocrisy in academia. The Guardian.

Federici, S. (2004). Caliban and the witch: women, the body and primitive accumulation. Brooklyn: Autonomedia.

Foucault, M. (1980). Power/knowledge: selected interviews and other writings, 1972-1977. New York: Pantheon Books.

Foucault, M. (1983). Berkeley Lectures - The Culture of the Self: Response to Questions [Archive Website]. Retrieved from http://www.generation-online.org/p/fpfoucault4.htm.

Foucault, M. (1991a). Discipline and punish: the birth of the prison. London: Penguin.

Foucault, M. (1991b). Governmentality. In G. Burchell, C. Gordon, \& P. Miller (Eds.), The Foucault effect: studies in governmentality (pp. 87-104). Chicago: University of Chicago Press.

Foucault, M. (2002). 'Omnes et Singulatim': toward a critique of political reason. In P. Faubion (Ed.), Essential works of Foucault, 1954-1984, volume 3: power (pp. 298-325). London: Penguin.

Foucault, M. (2003). Society must be defended: lectures at the Collège de France, 1975-76. Basingstoke: Palgrave Macmillan.

Foucault, M. (2007). Security, territory, population: lectures at the Collège de France, 1977-78. Basingstoke: Palgrave Macmillan.

Foucault, M. (2010). The birth of biopolitics: lectures at the Collège de France 1978-1979. Basingstoke: Palgrave Macmillan.

Geiger, R. L. (2004). Knowledge and money: research universities and the paradox of the marketplace. Stanford: Stanford University Press.

Gill, R. (2010). Breaking the silence: the hidden injuries of neo-liberal academia. In R. Ryan-Flood \& R. Gill (Eds.), Secrecy and silence in the research process: feminist reflections (pp. 228-244). London: Routledge.

Gill, R. (2014). Academics, cultural workers and critical labour studies. Journal of Cultural Economy, 7(1), 12-30.

Ginzburg, Y. (1975). Journey into the whirlwind. San Diego: Harcourt.

Glucksmann, A. (1975). La cuisinière et le mangeur d'hommes: Essai sur l'état, le marxisme, les camps de concentration. Paris: Seuil.

Gordon, C. (1991). Governmental Rationality: An Introduction. In: Burchell G, Gordon C and Miller P (eds) The Foucault Effect: Studies in Governmentality. Chicago, IL: University of Chicago Press, 1-51.

Hardt, M. (2008). Introduction: Labour at work. In C. Marazzi (Ed.), Capital and language: from the new economy to the war economy (pp. 7-11). Los Angeles: Semiotext(e).

Hardt, M., \& Negri, A. (2005). Multitude: war and democracy in the Age of Empire. London: Penguin.

Harvey, D. (2006). Limits to capital. London: Verso.

Harvey, D. (2010). The enigma of capital, and the crisis of capitalism. Oxford: Oxford University Press.

Holland, E. (1998). From schizophrenia to social control. In E. Kaufman (Ed.), Deleuze and Guattari: new mappings in politics, philosophy, and culture (pp. 65-73). Minneapolis: University of Minnesota Press.

Invisible Committee. (2009). The Coming Insurrection. Los Angeles: Semiotext(e).

Lazzarato, M. (2015). Governing by Debt. Los Angeles: Semiotext(e).

Levi, P. (1989). The drowned and the saved. London: Abacus.

Lordon, F. (2014). Willing Slaves of Capital: Spinoza \& Marx on Desire. New York: Verso.

Lorenz, C. (2012). If you're so smart, why are you under surveillance? Universities, neoliberalism and new public management. Critical Inquiry, 38(3), 599-629.

Marx, K. (1990). Capital: volume 1. London: Penguin.

McNay, L. (1992). Foucault and Feminism: Power, Gender and the Self. Cambridge: Polity Press.

Message, K. (2010). Body without organs. In A. Parr (Ed.), The Deleuze dictionary (pp. 37-39). Edinburgh: Edinburgh University Press.

New Formations. (2014). Societies of control—call for contributions. New Formations Journal. [Website]. http:// www.lwbooks.co.uk/journals/newformations/issue/nf8485.html. Accessed 11 June 2014.

Poulantzas, N. (2014). State, power, socialism. London: Verso.

Rancière, J. (2012). The intellectual and his people: staging the people, volume 2. London: Verso.

Saunders, D. B. (2010). Neoliberal ideology and public higher education in the United States. Journal for Critical Education Policy Studies, 8(1), 41-77.

Shalamov, V. T. (1994). Kolyma tales. London: Penguin.

Shore, C. (2008). Audit culture and illiberal governance. Anthropological Theory, 8(3), 278-298.

Solzhenitsyn, A. (2007a). The Gulag Archipelago, 1918-1956: volume one. New York: Harper Perennial. Solzhenitsyn, A. (2007b). The Gulag Archipelago, 1918-1956: volume two. New York: Harper Perennial. Solzhenitsyn, A. (2007c). The Gulag Archipelago, 1918-1956: volume three. New York: Harper Perennial.

Sparkes, A. C. (2007). Embodiment, academics, and the audit culture: a story seeking consideration. Qualitative Research, 7(4), 521-550. 
Strathern, M. (2000). Audit cultures: anthropological studies in accountability, ethics and the academy. London: Routledge. Thurston, R. (1993). The Stakhanovite movement: background to the Great Terror in the factories, 1935-1938. In 100Q8 14 J. Arch Getty \& R. T. Manning (Eds.), Stalinist terror: new perspectives (pp. 142-160). Cambridge: 1009 Cambridge University Press.

Trotsky, L. (1972). The revolution betrayed. New York: Pathfinder Press.

Virilio, P. (2006). Speed and politics: an essay on dromology. Los Angeles: Semiotext(e).

Virno, P., \& Hardt, M. (1996). Radical thought in Italy: a potential politics. Minneapolis: University of Minnesota Press. Welsh, J. (2016) The meta-disciplinary: capital at the threshold of control. Critical Sociology [Online First].

Zaretsky, E. (2005). Secrets of the soul: a social and cultural history of psychoanalysis. New York: Vintage Books. Zarod, K. (2006). Inside Stalin's Gulag: a true story of survival. Hove: Book Guild Publishing.

Zuidhof, P. W. (2015). Towards a post-neoliberal university: protest and complicity. Krisis, 2, 49-55. 